\title{
Synthesis of Nanocrystalline MgO Particles by Combustion Followed by Annealing Method Using Hexamine as a Fuel
}

\author{
S. Balamurugan, ${ }^{1}$ L. Ashna, ${ }^{2}$ and P. Parthiban ${ }^{1}$ \\ ${ }^{1}$ Advanced Nanomaterials Research Laboratory, Department of Nanotechnology, Noorul Islam Centre for Higher Education, \\ Kumaracoil, Thuckalay, Tamil Nadu 629 180, India \\ 2 Department of Biotechnology, Udaya School of Engineering, Udaya Nagar, Vellamodi, Ammandivilai, Tamil Nadu 629 204, India
}

Correspondence should be addressed to S. Balamurugan; scandium.chemistry@gmail.com

Received 28 January 2014; Accepted 18 May 2014; Published 3 June 2014

Academic Editor: Paresh Chandra Ray

Copyright (C) 2014 S. Balamurugan et al. This is an open access article distributed under the Creative Commons Attribution License, which permits unrestricted use, distribution, and reproduction in any medium, provided the original work is properly cited.

\begin{abstract}
In this work, nanocrystalline $\mathrm{MgO}$ particles were prepared through combustion method using magnesium nitrate as oxidizer and hexamine as a fuel. The materials obtained by combustion method were subsequently annealed at $800^{\circ} \mathrm{C}$ for $3 \mathrm{~h}$ to improve the crystallinity and phase purity. The obtained $\mathrm{MgO}$ nanomaterials were characterized by powder X-ray diffraction analysis (XRD), infrared (IR) spectroscopy, photoluminescence (PL), near-infrared (NIR) spectroscopy, and scanning electron microscopy (SEM). The cubic crystal structure with lattice parameter, $a=0.4210(4) \mathrm{nm}$ with average crystalline size of $22 \mathrm{~nm}$, is obtained for the nano$\mathrm{MgO}$ particles. The PL emission spectrum of nanocrystalline $\mathrm{MgO}$ materials exhibits three emission peaks at 432,465 , and $495 \mathrm{~nm}$ which are due to various structural defects. The SEM results expose the fact that the $\mathrm{MgO}$ nanomaterials are seemingly porous and highly agglomerated with fine particles. Owing to the higher reflectance of prepared nanocrystalline $\mathrm{MgO}$, it can be used as NIR reflective pigments. The present results prove that the combustion technique using hexamine can produce the materials with high crystallinity. To the best of our knowledge, this is the first report on the synthesis of nanocrystalline $\mathrm{MgO}$ materials by combustion method using hexamine as a fuel.
\end{abstract}

\section{Introduction}

Magnesium Oxide (designated as $\mathrm{MgO}$ ) is a semiconductor/insulator which crystallizes in rock salt/sodium chloride $(\mathrm{NaCl})$ type cubic structure [1]. Like $\mathrm{MgO}$, many binary oxides, for instance, $\mathrm{CaO}, \mathrm{SrO}, \mathrm{BaO}, \mathrm{NiO}$, and $\mathrm{CoO}$, also crystallize in rock salt structure [1]. $\mathrm{MgO}$ is an attractive material which has many potential applications [2-15], such as water purification, optoelectronics, microelectronics, and additive in heavy fuel oil, paint, gas separation, bactericides, and insulator in industrial cables, crucibles, and refractory materials. Further, it has been used as an oxide barrier in spin tunneling devices as well as substrate in super conducting and ferroelectric film. The $\mathrm{MgO}$ nanoparticles have high catalytic activity. Due to high specific surface area of nano$\mathrm{MgO}$ materials, they are found to catalyze efficiently in variety of organic reactions [16-18].

Several preparation routes [2-6, 9, 19-31], namely, combustion, microwave assisted synthesis, spinning disk reactor, wet chemical method, nonaqueous sol-gel method, chemical synthesis, microwave assisted sol-gel synthesis, surfactant assisted precipitation method, electrospinning technique, colloidal synthesis, $r f$ impulse discharge plasma, hard templating pathway, sol-gel method, and microwave hydrothermal process, have been reported for the preparation of nano$\mathrm{MgO}$ materials. For these synthesis methods, in literature, there are a variety of precursors, namely, magnesium nitrate, glycine, $\mathrm{Mg}(\mathrm{CHCOO})_{2}$ and ethylene glycol, $\mathrm{MgCl}_{2}$ and $\mathrm{NaOH}$, magnesium foil, toluene and $\mathrm{MgCl}_{2} \cdot 6 \mathrm{H}_{2} \mathrm{O}$, ammonia, polyvinyl alcohol, polyvinyl pyrrolidone, magnesium acetate tetrahydrate, $\mathrm{Mg}$ particle, tungsten wire, trioctylphosphine oxide (TOPO) and bis(cyclopentadienyl)magnesium (Cp2Mg), Mg rod electrode, and magnesium acetate, which have been reported for the preparation of $\mathrm{MgO}$ nanoparticles. Further, to prepare $\mathrm{MgO}$ nanomaterials, various fuels [215], namely, glycine, urea, combination of urea, glycine, and cellulose, propane, and 1,3 propane diol, have been used. Among these different fuels, urea $[4,8,10-12,14,15]$ is 
the most commonly used fuel in the preparation of nano$\mathrm{MgO}$ particles. In literature, for the synthesis of nano- $\mathrm{MgO}$ materials, magnesium nitrate and urea with the molar ratio $1: 1.67$ have been used as the oxidizer and fuel, respectively $[4,8,10-12,14,15]$. The (average) crystalline sizes of 15$60 \mathrm{~nm}$ [7], 16-19 nm [11], and $38 \mathrm{~nm}$ [14] have been reported for the $\mathrm{MgO}$ particles by different research group. The particle size obtained from microimages (SEM/TEM) has showed 300-350 nm (SEM) [7] and 20-25 (TEM) [4]. The combination of urea, glycine, and cellulose with the molar ratios $1: 1.67: 1.11: 0.42$ has showed the lowest particle size of $6.9 \mathrm{~nm}$ (XRD) and $5 \mathrm{~nm}$ (TEM) [6]. In addition to the reported various fuels [2-15], there are several efficient fuels which are available to perform the combustion synthesis. Hexamine is one of the efficient fuels to synthesize the nanoscale materials. To the best of our knowledge, there is no report available in literature on the synthesis of nano- $\mathrm{MgO}$ materials by hexamine as the fuel by combustion method. In this paper, we report the synthesis and characterization of nanocrystalline $\mathrm{MgO}$ particles by combustion method using hexamine as a fuel and magnesium nitrate as the precursor.

\section{Experimental Procedure}

The nanocrystalline $\mathrm{MgO}$ particles were prepared by combustion method using magnesium nitrate and hexamine (see the flow chart in Figure 1). The commercially available $\mathrm{Mg}\left(\mathrm{NO}_{3}\right)_{2} \cdot 6 \mathrm{H}_{2} \mathrm{O}$ was first dissolved in minimum quantity of deionised water. Then this solution was stirred at $300 \mathrm{rpm}$ for few minutes. After that, the fuel, hexamine $\left(\mathrm{C}_{6} \mathrm{H}_{12} \mathrm{~N}_{4}\right)$, dissolved in minimum quantity of deionised water was mixed to the magnesium nitrate solution and stirred well. Then, the solution combustion mixture was heated slowly in heating mantle until it gets ignited. When the temperature reached about $190^{\circ} \mathrm{C}$, combustion flame appeared. Figure 2 shows the observation of flame during the combustion of nitrate and fuel. After completion of combustion, the crude brown color powder was obtained. The obtained combustion product was annealed at $800^{\circ} \mathrm{C}$ for $3 \mathrm{hrs}$ in a groove rolled muffle furnace. After completion of annealing, the furnace was cooled to room temperature by switching off the power. The annealed product was white in color and taken for characterizations. The phase identification and purity of the annealed materials were tested by powder XRD and FT-IR spectroscopy. The photoluminescence (PL) property of the MgO powder sample was performed in a spectrofluorometer (ELICO SL 174) using 150 Watt Xenon Arc lamp as the excitation light source. The NIR spectrum of MgO powder was performed in a NIR Spectrophotometer (ELICO SL 153) using Quartz halogen lamp as the light source. The microstructural images and the elements present in the combustion-annealed $\mathrm{MgO}$ materials were performed in the scanning electron microscope, SEM (Jeol model; JSM-6390LV), attached with Energy Dispersive X-ray Analyzer (JED-2300).

\section{Results and Discussion}

3.1. XRD Pattern of Nano-MgO Powder. In the present work, $\mathrm{Mg}\left(\mathrm{NO}_{3}\right)_{2} \cdot 6 \mathrm{H}_{2} \mathrm{O}$ is used as oxidizer and $\mathrm{C}_{6} \mathrm{H}_{12} \mathrm{~N}_{4}$ is used as

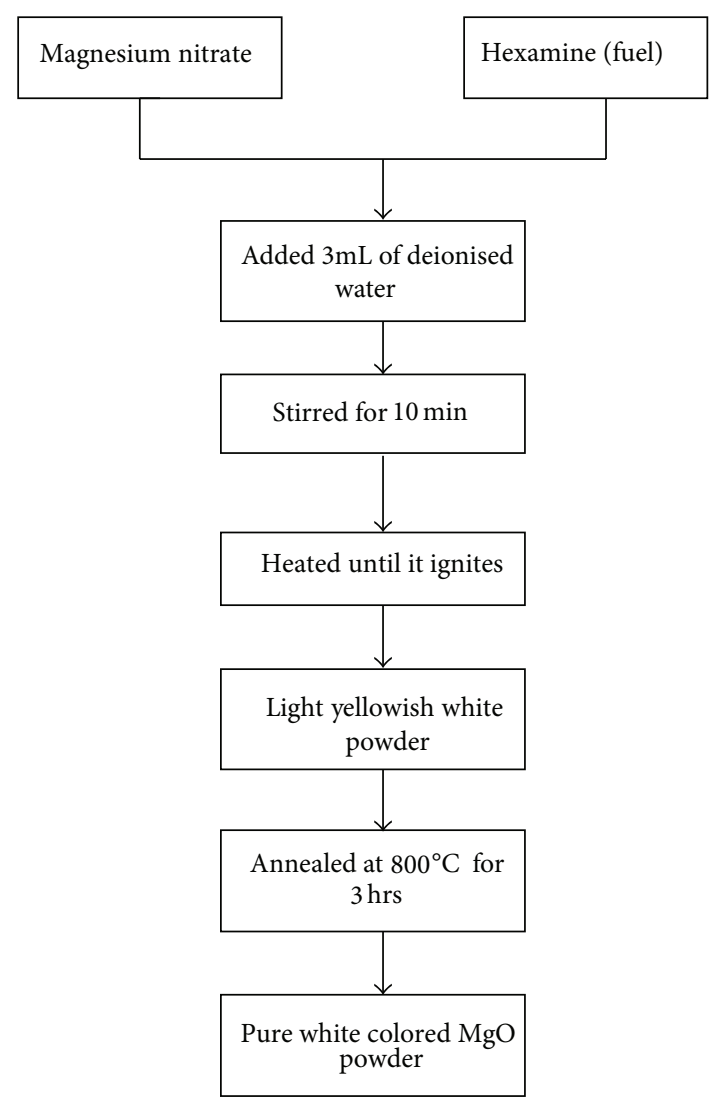

Figure 1: Experimental flow chart for the synthesis of $\mathrm{MgO}$ nanopowders by combustion followed by annealing method.

reducing agent. Similar to the oxidation number concept, the valency of the oxidizing elements is considered as negative and the reducing elements as positive in solution combustion calculations [32]. Accordingly, the elemental valency of C, $\mathrm{H}$, and $\mathrm{Mg}$ is $+4,+1$, and +2 , respectively, and the oxidizing valency of oxygen is taken as -2 . The valency of nitrogen is assumed to be zero. Based on this concept, the oxidizing valency of magnesium nitrate and the reducing valency of hexamine can be calculated as $\mathrm{Mg}\left(\mathrm{NO}_{3}\right)_{2} \cdot 6 \mathrm{H}_{2} \mathrm{O}=[+2-12+$ $0]=-10$ and $\mathrm{C}_{6} \mathrm{H}_{12} \mathrm{~N}_{4}=+24+12+0=36$. According to the equivalence ratio theory, for the combustion of magnesium nitrate and hexamine mixture, the molar ratio becomes $10 / 36=0.28$.

That is, $\Phi_{e}=\sum$ (Coefficient of oxidizing elements in specific formula $*$ valency $) /(-1) \sum$ (Coefficient of reducing elements in specific formula $*$ valency) $=10 / 36=0.28$. The 1:0.28 molar ratio of nitrate and hexamine is taken for the formation of $\mathrm{MgO}$ in the present combustion reaction. In order to see the variation in fuel concentration on the phase purity and particle size of $\mathrm{MgO}$ nanomaterial under different molar ratios, for example, $1: 0.1,1: 0.2,1: 0.28,1: 0.4,1: 0.5$, $1: 0.75$, and $1: 1$ conditions, the combustion syntheses were carried out. However, no significant effects are seen on their physical properties.

The powder XRD analyses were performed in the $2 \theta$ range between 20 and $80^{\circ}$ using $\mathrm{Cu} \mathrm{K}_{\alpha}$ radiation. In Figure 3, 


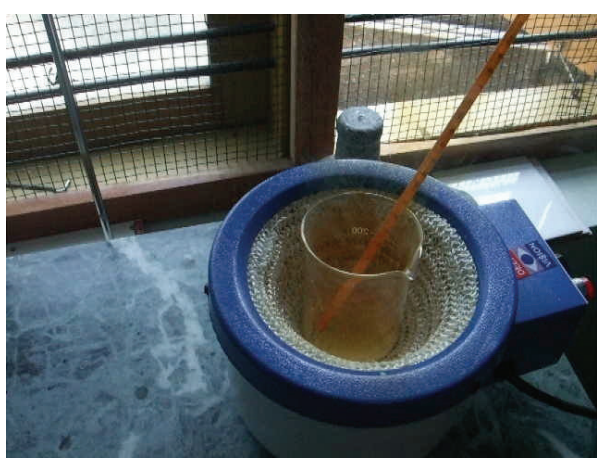

(a)

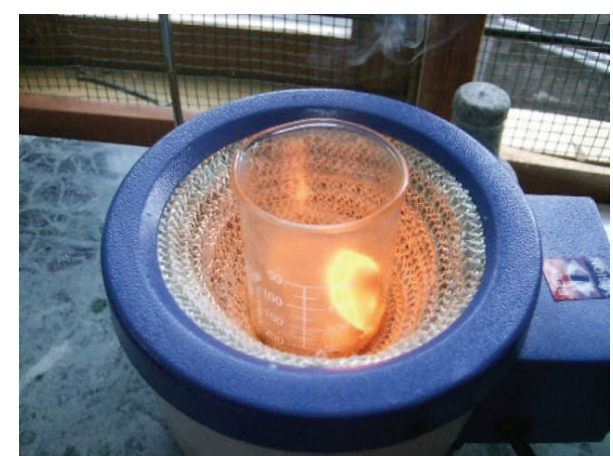

(b)

FIGURE 2: Slow evaporation (a) and observation of flame during combustion between nitrate and fuel (b) in the synthesis of $\mathrm{MgO}$.

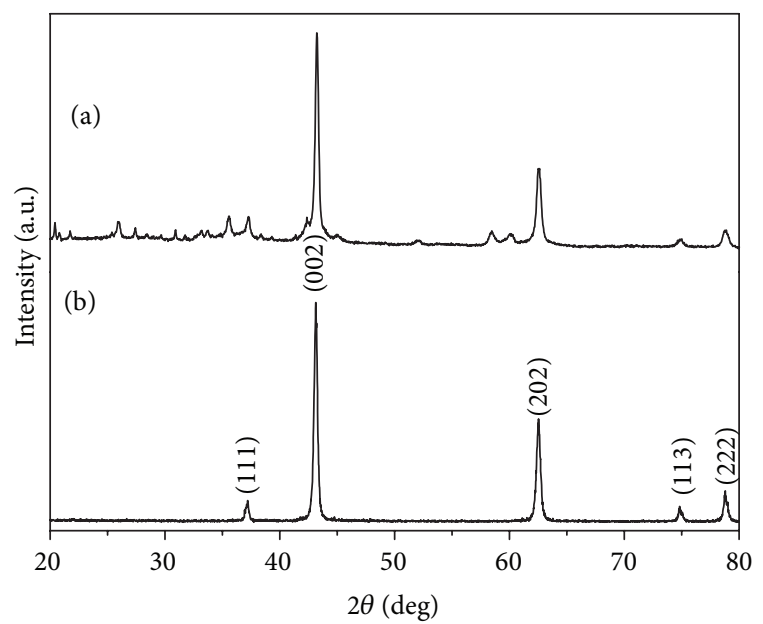

FIGURE 3: XRD patterns of as-prepared (a) and annealed (b) $\mathrm{MgO}$ nanoparticles.

the powder XRD patterns of both as-prepared and annealed $\mathrm{MgO}$ nanopowder are presented. From these XRD patterns, we observe that the annealed material is crystallized in single phase with cubic symmetry. The Bragg reflections are indexed on the basis of space group, Fm-3m (225), $\mathrm{Z}=4$ with cubic lattice parameter, and $a \sim 0.4210(4) \mathrm{nm}$ for the annealed sample. This present value is in good accordance with the literature reports. The Bragg reflections such as (111), (002), (202), (113), and (222) are seen in the $2 \theta$ range between 20 and $80^{\circ}$. All reflections are sharp with slight broadening. These reflect the crystalline nature of $\mathrm{MgO}$ nanopowder. The average crystalline size of $22 \mathrm{~nm}$ is obtained for the annealed nanocrystalline $\mathrm{MgO}$ powder from the Debye Scherrer formula using the XRD powder data [33].

3.2. FT-IR Spectrum of Nano-MgO Powder. The typical FTIR spectrum for the annealed $\mathrm{MgO}$ powder is depicted in Figure 4. From FT-IR analysis, the stretching vibration mode for the $\mathrm{Mg}-\mathrm{O}-\mathrm{Mg}$ compound is seen in the range of 487$677 \mathrm{~cm}^{-1}$ as a broad band. Two distinct bands are seen at the wave number ranges of $1014-1073 \mathrm{~cm}^{-1}$ and $1567-1641 \mathrm{~cm}^{-1}$ and are attributed to the bending vibration of absorbed water

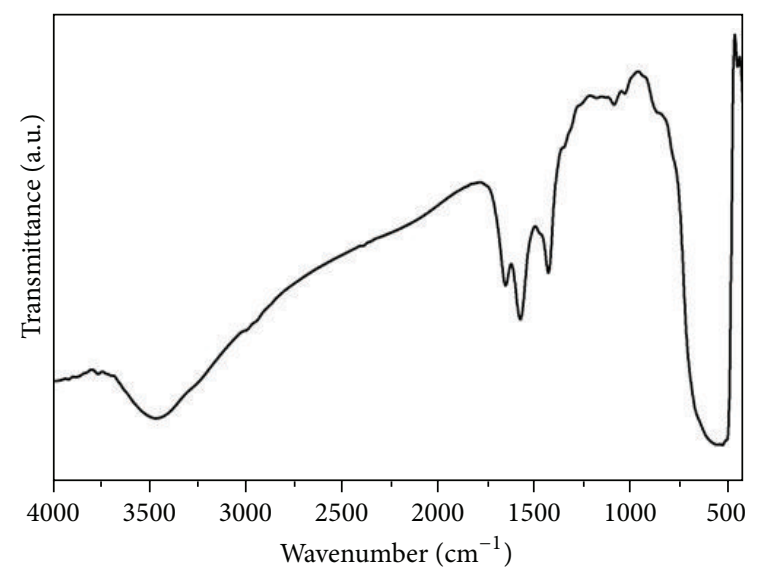

FIGURE 4: FT-IR spectrum of annealed MgO nanoparticles prepared by combustion followed by annealing method.

molecule and surface hydroxyl group $(-\mathrm{OH})$, respectively. A broad vibration band is seen in the wavenumber range 3325$3650 \mathrm{~cm}^{-1}$ due to $\mathrm{O}-\mathrm{H}$ stretching vibration of absorbed water molecule and surface hydroxyl group [11]. This is due to the aerial adsorptions of water molecule onto the $\mathrm{MgO}$ surface when it is exposed to atmosphere. The FT-IR absorption peak seen at the wavenumber $1420 \mathrm{~cm}^{-1}$ is assigned to the asymmetric stretching of the carbonate ion, $\mathrm{CO}_{3}{ }^{2-}$ species [11].

3.3. Optical Properties of Nano-MgO Powder. The PL emission spectrum of annealed nanocrystalline $\mathrm{MgO}$ powder is shown in Figure 5. The PL emission spectrum was recorded at $385 \mathrm{~nm}$ as an excitation wavelength with bandwidth equal to $5 \mathrm{~nm}$ and scanning rate equal to $200 \mathrm{~nm} / \mathrm{sec}$. The $\mathrm{PL}$ emission spectrum reveals three emission peaks at 432, 465, and $495 \mathrm{~nm}$ in $400-500 \mathrm{~nm}$ emission band range, in which the $432 \mathrm{~nm}$ emission arises from the defect band transition and ${ }^{3} \mathrm{~B}_{1 \mathrm{u}} \rightarrow{ }^{1} \mathrm{~A}_{\mathrm{g}}$ from $\mathrm{F}_{2}{ }^{2+}$ defect centre occupied in $\mathrm{D}_{2 \mathrm{~h}}$ symmetry [11, 34]. The 465 and $495 \mathrm{~nm}$ blue emissions are owing to the recombination of electrons with oxygen vacancies (i.e., F centre). These vacancies are possibly generated 


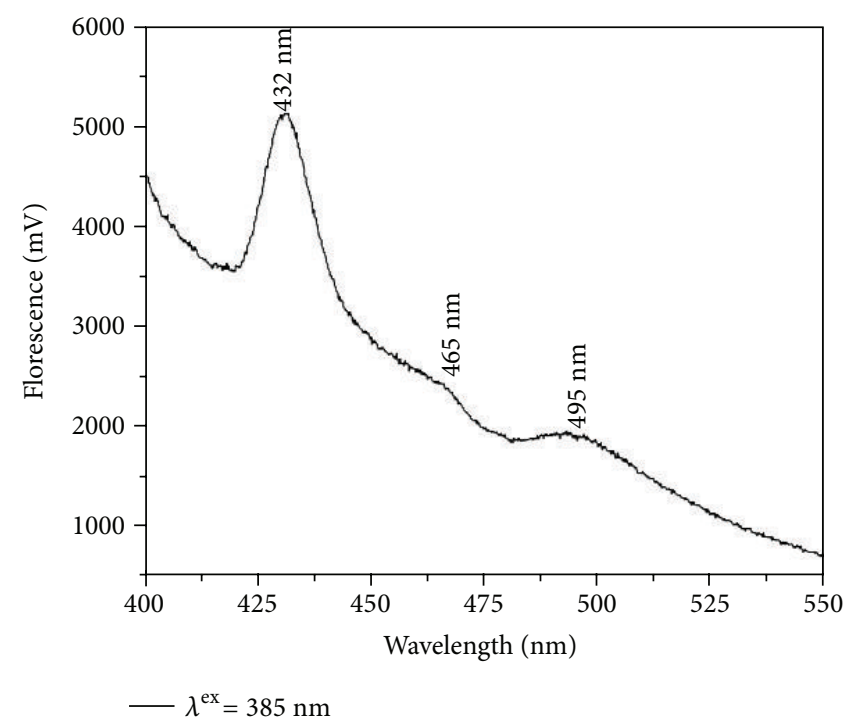

FIGURE 5: Room temperature PL spectrum of annealed MgO nanoparticles under the excitation wavelength of $385 \mathrm{~nm}$.

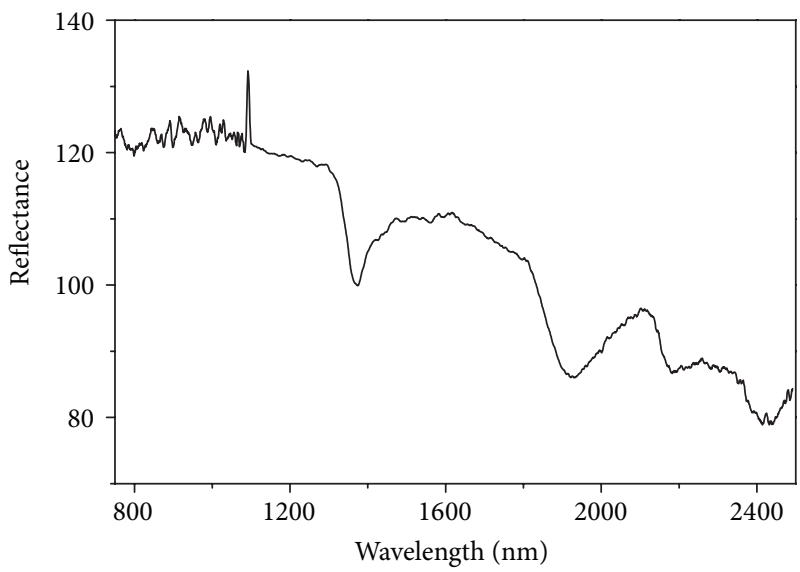

FIGURE 6: NIR spectrum of annealed MgO nanoparticles prepared by combustion followed by annealing method.

by various factors, namely, unbalanced oxygenation during self-ignition, subsequential crystallization process, and $\mathrm{Mg}$ vacancies and interstitials [11,35]. Figure 6 depicts the NIR spectrum of annealed nano- $\mathrm{MgO}$ powder as a function of wavelength. Quite similar to the report of Jeevanandam et al. [36], our NIR spectrum of nano- $\mathrm{MgO}$ powder shows higher reflectance value in the region $800-1300 \mathrm{~nm}$. This is due to the smaller crystalline size of combustion-annealed nano- $\mathrm{MgO}$ powder. Owing to the higher reflectance of nano-MgO, it can be used as NIR reflective pigments [36].

3.4. Microstructure Analysis of $M g O$ by SEM. In order to see the morphology and the particle size of the annealed $\mathrm{MgO}$, the SEM images were taken in the scanning electron microscope (SEM; Jeol model JSM-6390LV instrument) (see Figures $7(\mathrm{a})-7(\mathrm{~d})$ ). The SEM images are shown in different magnifications. The SEM results reveal that the annealed $\mathrm{MgO}$ nanomaterials are seemingly porous and highly agglomerated with the nanoentities. Thus the particle size of $\mathrm{MgO}$ could not be seen accurately from the present SEM results (Figure 8). Due to the porous nature of $\mathrm{MgO}$, the combustion-annealed $\mathrm{MgO}$ nanomaterials may play a major role in gas sensing application.

\section{Conclusion}

From our present work, it is concluded that it is easy to prepare $\mathrm{MgO}$ nanoparticles by combustion method using magnesium nitrate as oxidizer and hexamine as a fuel. The obtained white color $\mathrm{MgO}$ materials were analyzed using various characterization techniques. The XRD pattern confirmed the crystallinity and phase purity of the annealed nano- $\mathrm{MgO}$ powder. The average particle size calculated from the diffraction peaks was found to be $22 \mathrm{~nm}$. The SEM result revealed that the powder is porous and agglomerated with polycrystallite nanoparticles. The $\mathrm{MgO}$ materials obtained by combustion-annealing method using hexamine may prove 


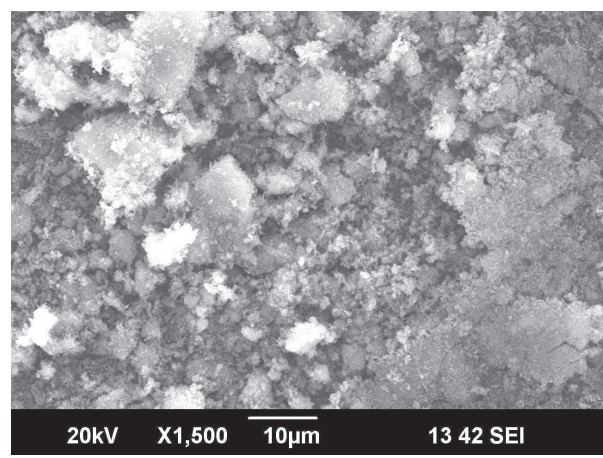

(a)

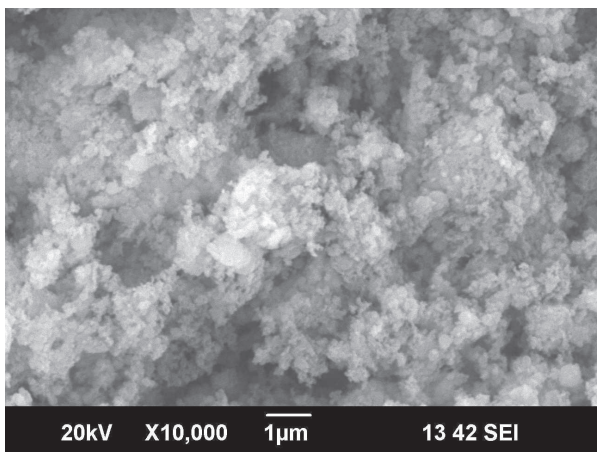

(c)

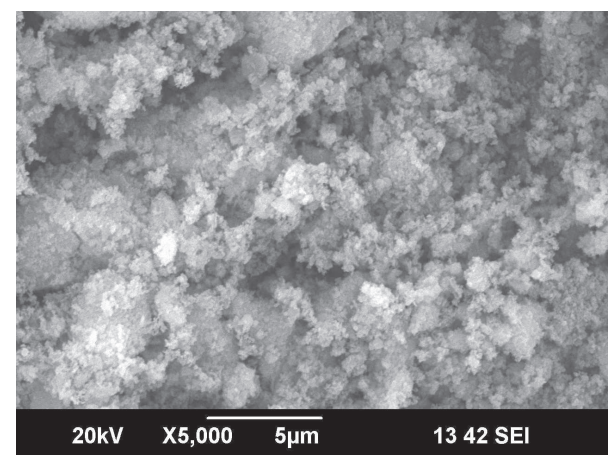

(b)

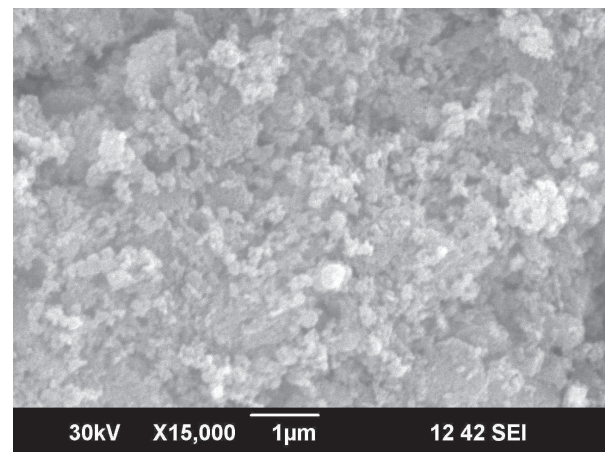

(d)

FIgURE 7: (a-d) SEM microimages of annealed MgO nanopowders obtained by combustion followed byannealing method.

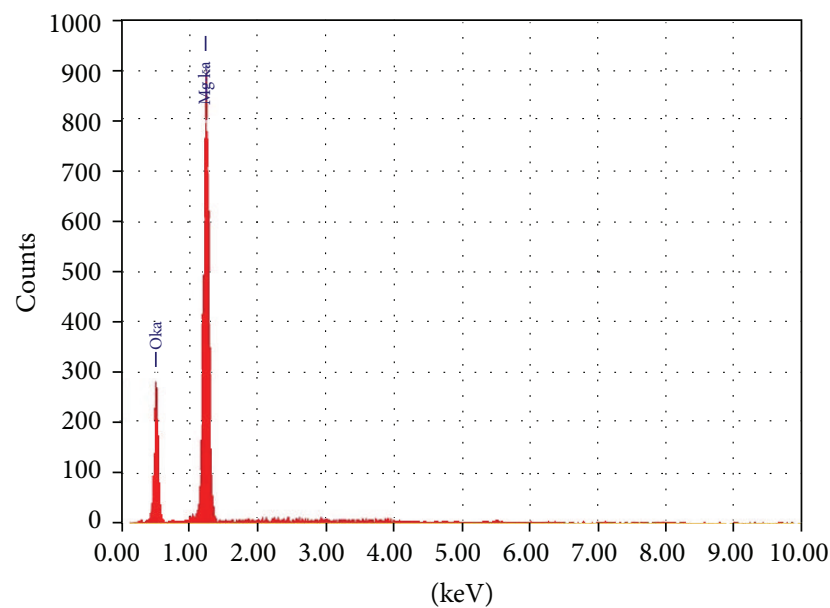

Figure 8: EDX spectrum of annealed MgO nanopowders.

potential applications in pigments, catalyst, water purification, optoelectronics, bactericides, substrate, insulator, crucibles, and refractory materials.

\section{Conflict of Interests}

The authors declare that there is no conflict of interests regarding the publication of this paper.

\section{Acknowledgments}

The author S. Balamurugan is thankful to DST-SERB, Government of India, for the research Grant (Sanction no. CS-108/2011) under the Fast Track-Young Scientist award scheme. Further, the authors are thankful to Noorul Islam Centre for Higher Education for the encouragement.

\section{References}

[1] G. Spoto, E. N. Gribov, G. Ricchiardi et al., "Carbon monoxide $\mathrm{MgO}$ from dispersed solids to single crystals: a review and new advances," Progress in Surface Science, vol. 76, no. 3-5, pp. 71-146, 2004.

[2] K. Kaviyarasu and P. A. Devarajan, "A versatile route to synthesize $\mathrm{MgO}$ nanocrystals by combustion technique," Der Pharma Chemica, vol. 3, no. 5, pp. 248-254, 2011.

[3] S. Suresh and D. Arivuoli, "Synthesis and characterization of $\mathrm{Pb}+$ doped $\mathrm{MgO}$ nanocrystalline particles," Digest Journal of Nanomaterials and Biostructures, vol. 6, no. 4, pp. 1597-1603, 2011.

[4] F. Gu, S. F. Wang, M. K. Lü et al., "Combustion synthesis and luminescence properties of $\mathrm{Dy}^{3+}$-doped $\mathrm{MgO}$ nanocrystals," Journal of Crystal Growth, vol. 260, no. 3-4, pp. 507-510, 2004.

[5] B. Nagappa and G. T. Chandrappa, "Mesoporous nanocrystalline magnesium oxide for environmental remediation," Microporous and Mesoporous Materials, vol. 106, no. 1-3, pp. 212-218, 2007.

[6] S. M. Maliyekkal, K. R. Antony, and T. Pradeep, "High yield combustion synthesis of nanomagnesia and its application for 
fluoride removal," Science of the Total Environment, vol. 408, no. 10, pp. 2273-2282, 2010.

[7] K. V. Rao and C. S. Sunandana, "Structure and microstructure of combustion synthesized $\mathrm{MgO}$ nanoparticles and nanocrystalline $\mathrm{MgO}$ thin films synthesized by solution growth route," Journal of Materials Science, vol. 43, no. 1, pp. 146-154, 2008.

[8] V. R. Orante-Barrn, L. C. Oliveira, J. B. Kelly et al., "Luminescence properties of $\mathrm{MgO}$ produced by solution combustion synthesis and doped with lanthanides and Li," Journal of Luminescence, vol. 131, no. 5, pp. 1058-1065, 2011.

[9] I. E. Agranovski, A. Y. Ilyushechkin, I. S. Altman, T. E. Bostrom, and M. Choi, "Methods of introduction of $\mathrm{MgO}$ nanoparticles into Bi-2212/Ag tapes," Physica C, vol. 434, no. 1, pp. 115-120, 2006.

[10] T. Mathews, R. Subasri, and O. M. Sreedharan, "A rapid combustion synthesis of $\mathrm{MgO}$ stabilized $\mathrm{Sr}$ - and $\mathrm{Ba}-\beta$-alumina and their microwave sintering," Solid State Ionics, vol. 148, no. 1-2, pp. 135-143, 2002.

[11] N. C. S. Selvam, R. T. Kumar, L. J. Kennedy, and J. J. Vijaya, "Comparative study of microwave and conventional methods for the preparation and optical properties of novel MgO-micro and nano-structures," Journal of Alloys and Compounds, vol. 509, no. 41, pp. 9809-9815, 2011.

[12] L. C. Oliveira, E. D. Milliken, and E. G. Yukihara, "Development and characterization of MgO:Nd,Li synthesized by solution combustion synthesis for $2 \mathrm{D}$ optically stimulated luminescence dosimetry," Journal of Luminescence, vol. 133, pp. 211-216, 2013.

[13] K. D. Bhatte, D. N. Sawant, K. M. Deshmukh, and B. M. Bhanage, "Additive free microwave assisted synthesis of nanocrystalline $\mathrm{Mg}(\mathrm{OH})_{2}$ and $\mathrm{MgO}$," Particuology, vol. 10, no. 3, pp. 384387, 2012.

[14] R. Kumar, A. Subramania, N. T. K. Sundaram, G. V. Kumar, and I. Baskaran, "Effect of MgO nanoparticles on ionic conductivity and electrochemical properties of nanocomposite polymer electrolyte," Journal of Membrane Science, vol. 300, no. 1-2, pp. 104-110, 2007.

[15] F. Granados-Correa, J. Bonifacio-Martínez, V. H. Lara, P. Bosch, and S. Bulbulian, "Cobalt sorption properties of MgO prepared by solution combustion," Applied Surface Science, vol. 254, no. 15, pp. 4688-4694, 2008.

[16] V. Štengl, S. Bakardjieva, M. Maříková, P. Bezdička, and J. Šubrt, "Magnesium oxide nanoparticles prepared by ultrasound enhanced hydrolysis of Mg-alkoxides," Materials Letters, vol. 57, no. 24-25, pp. 3998-4003, 2003.

[17] M. B. Gawande, P. S. Branco, K. Parghi et al., "Synthesis and characterization of versatile $\mathrm{MgO}-\mathrm{ZrO}_{2}$ mixed metal oxide nanoparticles and their applications," Catalysis Science \& Technology, vol. 1, no. 9, pp. 1653-1664, 2011.

[18] Z. Camtakan, S. Erenturk, and S. Yusan, "Magnesium oxide nanoparticles: preparation, characterization, and uranium sorption properties," Environmental Progress and Sustainable Energy, vol. 31, no. 4, pp. 536-543, 2012.

[19] S. Makhluf, R. Dror, Y. Nitzan, Y. Abramovich, R. Jelinek, and A. Gedanken, "Microwave-assisted synthesis of nanocrystalline $\mathrm{MgO}$ and its use as a bacteriocide," Advanced Functional Materials, vol. 15, no. 10, pp. 1708-1715, 2005.

[20] C. Y. Tai, C.-T. Tai, M.-H. Chang, and H.-S. Liu, "Synthesis of magnesium hydroxide and oxide nanoparticles using a spinning disk reactor," Industrial and Engineering Chemistry Research, vol. 46, no. 17, pp. 5536-5541, 2007.

[21] M. A. Shah, "Preparation of MgO nanoparticles with water," African Physical Review, vol. 21, no. 4, pp. 21-23, 2010.
[22] M. Sundrarajan, J. Suresh, and R. Rajiv Gandhi, "A comparative study on antibacterial properties of $\mathrm{MgO}$ nanoparticles prepared under different calcination temperature," Digest Journal of Nanomaterials and Biostructures, vol. 7, no. 3, pp. 983-989, 2012.

[23] T. Athar, A. Hakeem, and W. Ahmed, "Synthesis of MgO nanopowder via non aqueous sol-gel method," Advanced Science Letters, vol. 7, pp. 27-29, 2012.

[24] J.-Y. Park, Y.-J. Lee, K.-W. Jun, J.-O. Baeg, and D. J. Yim, "Chemical synthesis and characterization of highly oil dispersed $\mathrm{MgO}$ nanoparticles," Journal of Industrial and Engineering Chemistry, vol. 12, no. 6, pp. 882-887, 2006.

[25] H. Mirzaei and A. Davoodnia, "Microwave assisted sol-gel synthesis of $\mathrm{MgO}$ nanoparticles and their catalytic activity in the synthesis of Hantzsch 1,4-dihydropyridines," Chinese Journal of Catalysis, vol. 33, no. 9, pp. 1502-1507, 2012.

[26] F. Meshkani and M. Rezaei, "Effect of process parameters on the synthesis of nanocrystalline magnesium oxide with high surface area and plate-like shape by surfactant assisted precipitation method," Powder Technology, vol. 199, no. 2, pp. 144-148, 2010.

[27] R. Murugan, K. Ramamoorthy, S. Sundarrajan, and S. Ramakrishna, "Magnesium oxide nanotubes: synthesis, characterization and application as efficient recyclable catalyst for pyrazolyl 1,4-dihydropyridine derivatives," Tetrahedron, vol. 68, no. 35, pp. 7196-7201, 2012.

[28] S. Iizuka and T. Muraoka, "Single-crystal MgO hollow nanospheres formed in RF impulse discharge plasmas," Journal of Nanomaterials, vol. 2012, Article ID 691874, 6 pages, 2012.

[29] W.-C. Li, A.-H. Lu, C. Weidenthaler, and F. Schüth, "Hardtemplating pathway to create mesoporous magnesium oxide," Chemistry of Materials, vol. 16, no. 26, pp. 5676-5681, 2004.

[30] M. P. Dharshini, G. Sr. Jayam, V. Shally, and D. Manoharan, "Effect of variation of precursor concentration on the structural and optical characteristics of $\mathrm{MgO}$ nanoparticles," Applied Research and Development Institute Journal, vol. 6, no. 17, pp. 150-158, 2012.

[31] F. Al-Hazmi, F. Alnowaiser, A. A. Al-Ghamdi et al., "A new large-scale synthesis of magnesium oxide nanowires: structural and antibacterial properties," Superlattices and Microstructures, vol. 52, no. 2, pp. 200-209, 2012.

[32] K. C. Patil, M. S. Hegde, T. Rattan, and S. T. Aruna, Chemistry of Nanocrystalline Oxide Materials: Combustion Synthesis, Properties and Applications, World Scientific Publishing, 2008.

[33] S. Balamurugan and K. Melba, " $\mathrm{Zn}_{1-x} \mathrm{Cu}_{x} \mathrm{O}(0.02 \leq x \leq$ 0.1) Nanomaterials prepared by ball milling, citrate sol gel, and molten salt flux methods," Journal of Nanoscience and Nanotechnology, vol. 14, pp. 1-9, 2014.

[34] A. Kumar, S. Thota, S. Varma, and J. Kumar, "Sol-gel synthesis of highly luminescent magnesium oxide nanocrystallites," Journal of Luminescence, vol. 131, no. 4, pp. 640-648, 2011.

[35] Y. Hao, G. Meng, C. Ye, X. Zhang, and L. Zhang, "Kineticsdriven growth of orthogonally branched single-crystalline magnesium oxide nanostructures," Journal of Physical Chemistry B, vol. 109, no. 22, pp. 11204-11208, 2005.

[36] P. Jeevanandam, R. S. Mulukutla, M. Phillips, S. Chaudhuri, L. E. Erickson, and K. J. Klabunde, "Near infrared reflectance properties of metal oxide nanoparticles," Journal of Physical Chemistry C, vol. 111, no. 5, pp. 1912-1918, 2007. 

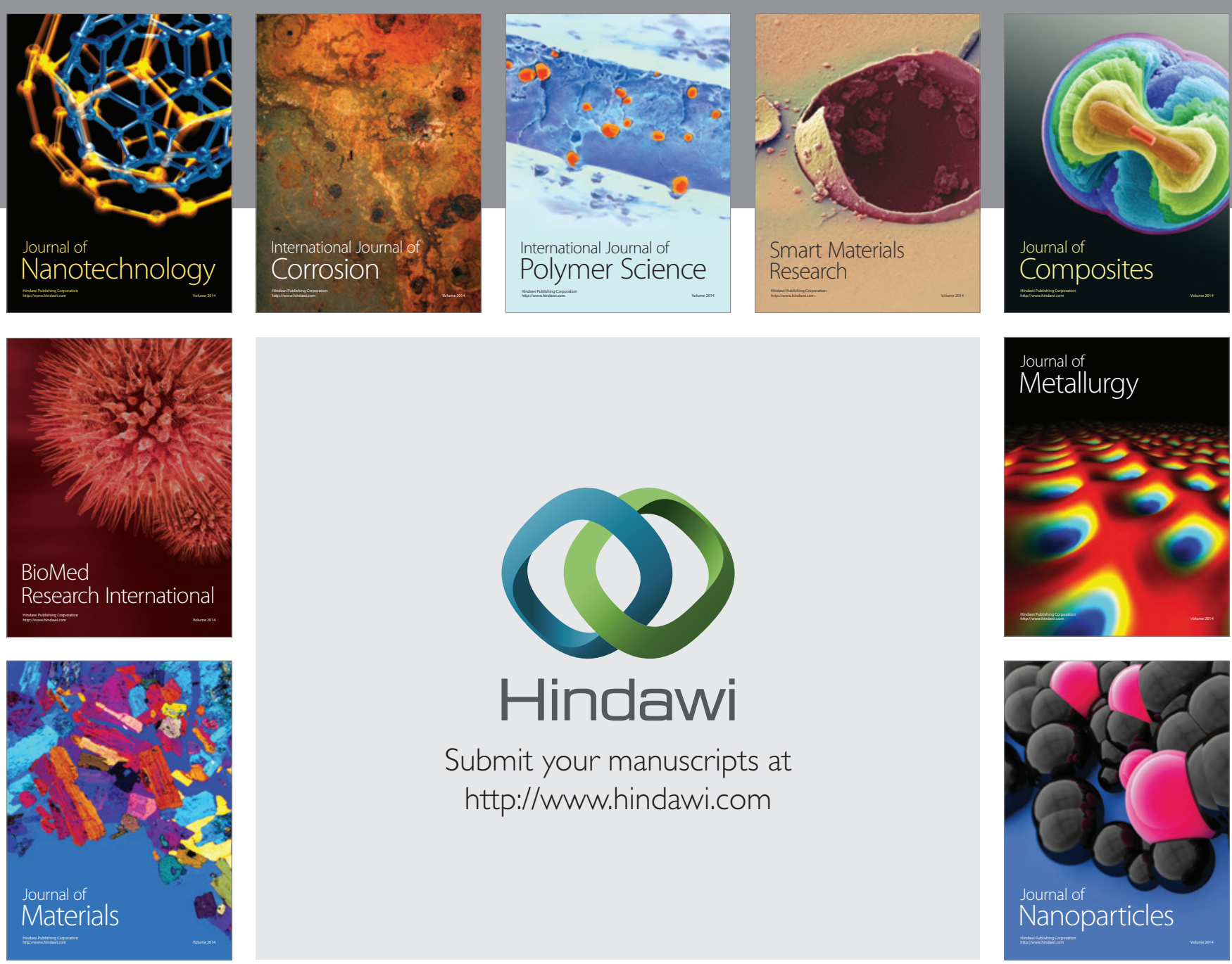

Submit your manuscripts at http://www.hindawi.com
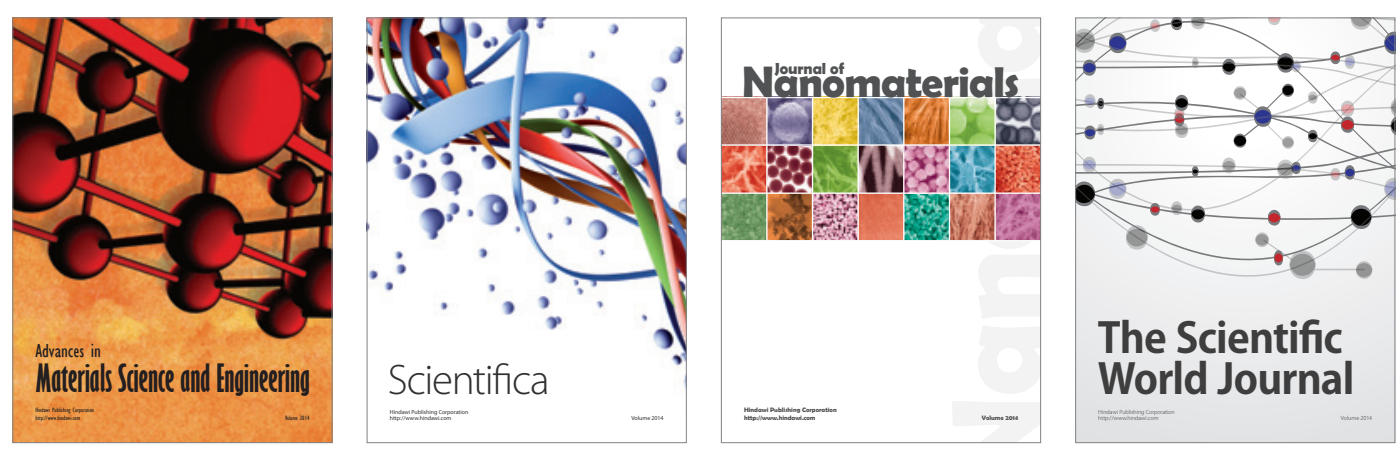

\section{The Scientific World Journal}
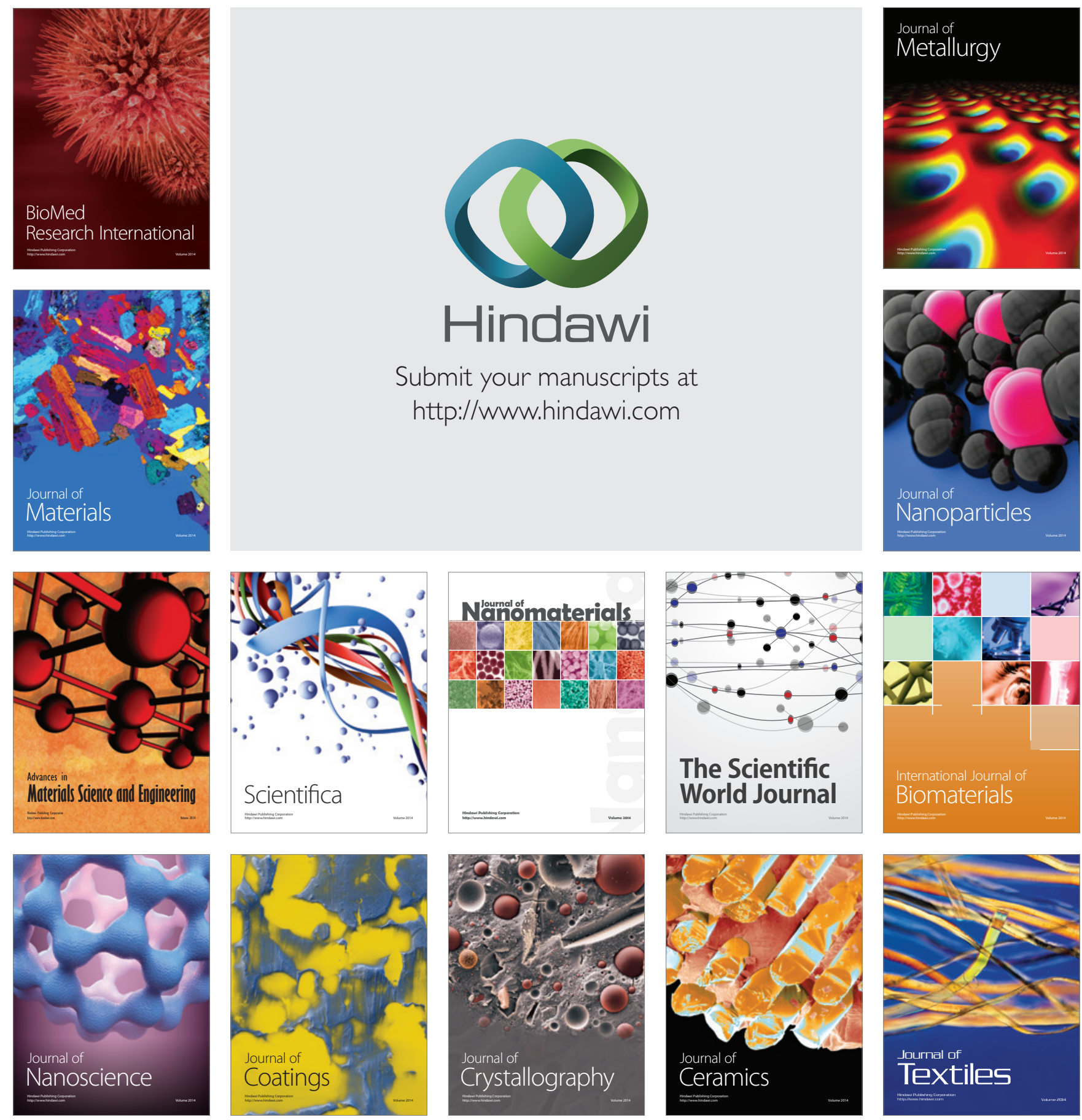